\title{
EFFECT OF TRAINING ON SMALL-SCALE RICE PRODUCTION IN NORTHERN GHANA
}

\author{
Benjamin Tetteh Anang ${ }^{1}$ - Joseph A. Awuni ${ }^{2}$ \\ ${ }^{1}$ Department of Agricultural Economics and Extension, Faculty of Agriculture, University for Development \\ Studies, Tamale, Ghana E-mail: benjamin.anang@uds.edu.gh

\begin{abstract}
${ }^{2}$ Department of Agricultural and Resource Economics, Faculty of Agribusiness and Communication Sciences, University for Development Studies, Tamale, Ghana E-mail: josephawunigh@yahoo.co.uk
\end{abstract}

\begin{abstract}
Training in modern farming methods enables farm households in developing countries to improve agricultural productivity. Notwithstanding the efforts of governmental and non-governmental organisations to provide farmers with agricultural training, productivity remains low. The existing literature provides little empirical evidence of the effect of training on agricultural productivity in Ghana. This study therefore seeks to bridge this gap by investigating small scale rice farmers' participation in agricultural training programmes and its effect on productivity in northern Ghana. A treatment effect model was used to account for sample selection bias. The results indicated that participation in training increased with the number of extension visits, group membership, access to credit and the degree of specialisation in rice production. Furthermore, total output and labour productivity both increased with participation in training but the relationship with land productivity (yield) was insignificant. On average, participation in training was associated with 797kg increase in rice output, while labour productivity increased by $7.3 \mathrm{~kg} /$ man-day. With the exception of farm capital, all the production inputs had a positively significant relationship with output suggesting sub-optimal use of capital in production. The study concludes that farmers' training needs are not adequately being met while inadequate capital is constraining farm output. Increasing access to extension service and involving farmer-based organisations in the design and implementation of training programmes will enhance participation and farm performance.
\end{abstract}

Keywords: Agricultural training, labour productivity, rice output, small-scale farmers, treatment effects model. (JEL Classification: C21, D24, Q12)

\section{INTRODUCTION}

Agriculture is largely a rural phenomenon in most developing countries and characterised by small-scale production. Widespread disparities in socio-economic conditions exist between rural and urban communities in Ghana. Consequently, both the central and local government authorities have placed emphasis on accelerating socioeconomic development of rural communities through improvements in agricultural production. This is as a result of the recognition of the fact that promotion of agricultural production is the best policy option to alleviate rural poverty and food insecurity and thereby promote rural livelihoods and socio-economic growth (DIAO et al. 2010; FAO 2012).

Most small-scale arable crop producers in developing countries including Ghana have low level of technical knowhow which is a drawback to agricultural production(WIGGINS 2000). This situation is linked to low levels of education among producers, lack of access to extension advice and training, which altogether affect the human capital which is critical to farm performance (CLARKE et al. 2017). According to GIRGIN (2011), the role of human capital in promoting growth in productivity has gained the interest of researchers since the middle of the twentieth century. Improving the human capital has been recognized as one important step to enhance productivity in all sectors of production, hence the emphasis on quality education, training and extension advice to producers all over the world. According to the existing literature, productivity increases can be brought about by investment in human capital (BRENYA, 2014; PARDEY et al. 1992; ROSEGRANT and EVENSON, 1992). Human capital may be defined as formal/informal education and 
training that promote economic growth through enhancement of firms' output and productivity. The human capital variables that require investment include education, extension, training and technology research. Human capital has a direct effect on productivity through its effect on how resources are used and combined by farmers. Human capital also affects acquisition and implementation of information as well as producers' ability to adapt to new technology. Hence efforts at improving the value of the human capital through education, access to information and training have become imperative in the modern era as means to enhance productivity. This study focuses on training as an important form of human capital that requires investment for improvement of farm performance in developing countries.

The extant academic literature provides evidence of the major role training plays in enhancing productivity. COLOMBO and STANCA (2014) investigated the impact of training on productivity using a panel data of Italian firms and found that training had a positive and significant impact on productivity. In a study on the impact of training on technology adoption and productivity of rice farming in Tanzania, NAKANO et al. (2015) observed that training enhanced adoption of improved varieties and farmers' yield. GAUTAM et al. (2017) examined the impact of training vegetables farmers in integrated pest management in Bangladesh and found that eggplant farmers who received training achieved higher crop yield and gross margin. In another study on the impact of Farmers' Training Centres in Eastern Ethiopia, WORDOFA and SASSI (2017) observed a significant average gain in farm income by participants who received training.

Training is a human capital variable which according to human capital theory enhances the skills of individuals, thereby contributing positively to output and productivity. Knowledgeable workers constitute a firm's most important asset and sustain the firm's competitiveness (LUCAS, 1993). Besides, human capital accumulation ensures sustainable longterm economic growth. Several empirical studies indicate positive effects of education and training on productivity growth. Compared to general education, training has additional benefits that are more obvious (ISMAIL et al., 2011). Training equips individuals with specific skills and competencies that lead to higher firm productivity.

Several factors are known to influence smallholders' access to training, services and information in rural communities. These factors include socio-economic, demographic and institutional factors such as gender, age, educational status, location, extension contact, among others. Identifying the factors influencing the participation of smallholder farmers in rice training programmes will provide useful insights to guide policy makers and organisations serving the training needs of small-scale farmers in Ghana and other developing countries.

Despite the important role of agricultural training in enhancing farm performance, there is little research attention on the subject. Information on the training needs of smallholders and the effect of training on farm performance is essential to providers of farmer training programmes to tailor their training activities to meet the needs of farmers. Due to the lack of research in this subject area, the current study sought to find out from small -scale rice farmers whether they were able to attend a training programme during the cropping year under review. The binary response was captured as 1 for attendees and 0 for non-attendees. Participation in training meant that the farmer was informed of the training programme and invited to attend. Training programmes included those offered by the Ministry of Food and Agriculture through its extension directorate, as well as training offered by nongovernmental organisations such as the Association of Church Development Projects (ACDEP). The results of the study will highlight the factors inhibiting participation in agricultural training programmes and provide a measure of the effect of training on farm performance, particularly farm output and labour productivity.

\section{METHODOLOGY}

\section{Study area}

The study was carried out in northern Ghana, which is comprised of the Upper East, Upper West and Northern Regions. The area, unlike the rest of the country, falls within the savannah agro-ecological zone which is characterized by only one raining season. The mono-modal rainfall distribution allows only one cropping season spanning a period of 5 to 6 months. Mean annual rainfall is $1,000 \mathrm{~mm}$ in the Upper East Region and 1,200 $\mathrm{mm}$ in the south-eastern part of the Northern Region. Northern Ghana has a total area of $98,000 \mathrm{~km} 2$ with $16,000 \mathrm{~km} 2$ being intensely farmed and about $8,000 \mathrm{~km} 2$ being less intensely farmed (AL-HASSAN, 2008). Northern Ghana is regarded as the bread basket of the country due to its high agricultural potential. However, poverty levels in the area are higher, relative to other parts of the country. In addition, the areas accounts for about $70 \%$ of the area under rice cultivation in Ghana. The productivity of rice in the area is however low due to low soil fertility, lack of credit access and low adoption of improved technologies (SRID-MOFA, 2011).

\section{Sampling and data collection}

Data for the study was obtained from a farm household survey conducted during the 2013/2014 farming season. A stratified multi-stage sampling technique was used to select the smallholder rice farmers who were interviewed using a questionnaire. The three largest irrigation schemes in northern Ghana were purposively sampled for the study. These are the Tono Irrigation and Vea schemes, located in the Upper East Region, and the Botanga Irrigation Scheme which is located in the Northern Region. Five communities were randomly selected from the catchment area of the irrigation schemes. The respondents were stratified into irrigators and non-irrigators and equal samples of irrigators and nonirrigators were randomly selected to give a total sample of 300 respondents. 


\section{Treatment effect model}

Selection bias is a common problem in evaluation studies. Selection bias typically arises when there are unobserved factors that influence the selection equation (participation in training) and the outcome variable (output or labour productivity). Furthermore, farmers may self-select into either category or some farmers may be excluded from participation, thus resulting in sample selection bias. One approach in the extant literature used to account for sample selection bias is the treatment effect model. The treatment effect model can be differentiated from Heckman's two-stage sample selection model by the treatment condition (in this case participation in training) entering the substantive equation to measure the direct effect on the response variable (MADDALA, 1983).

In this study, the selection equation is presented as an index function with an unobserved continuous variable $\left(A_{\mathrm{i}}^{*}\right)$ as follows:

$$
\begin{gathered}
A_{i}^{*}=\gamma Z_{i}+u_{i} \\
A_{i}= \begin{cases}1 & \text { if } A_{i}^{*}>0 \\
0 & \text { otherwise }\end{cases}
\end{gathered}
$$

where $A_{i}^{*}$ represents the probability of participation in training such that $A_{\mathrm{i}}=1$ if the respondent received training and $A_{\mathrm{i}}=$ 0 if the respondent did not receive training. $\mathrm{Zi}$ is a vector of independent variables that explain participation in training.

The substantive regression equation (i.e. the Cobb-Douglas production function) for the study is denoted by:

$$
Y_{i}=X_{i} \beta+A_{i} \delta+u_{2}
$$

where $Y_{i}$ is rice output, $X_{i}$ represents a vector of independent variables, $\delta$ measures the effect of training on output and $\mathrm{Ai}$ is defined as an index variable indicating whether or not the farmer participated in training. Adding the inverse Mill's ratio gives the following equation according to MADDALA (1993):

$$
\ln Y_{i}=\beta^{\prime}\left(\Phi_{i} \ln X_{i}\right)+\delta^{\prime}\left(\Phi_{i} A_{i}\right)+\sigma \phi_{i}+u_{3}
$$

where $\varphi_{i}$ and $\Phi_{i}$ are the probability density function (PDF) and the cumulative density function (CDF) respectively of the standard normal distribution, and $\Phi_{i}=\Phi\left(\mathrm{Zi}^{\prime} \gamma\right)$. u3 is the two-sided error term.

2.4 Quantifying the average effect of training on rice production

In order to quantify the effect of training on rice output and labour productivity, the study estimated the average treatment effect on the treated (ATT), which is an important impact parameter in studies on evaluation and impact analysis. The average treatment effect (ATE) given the observable data is denoted by:

$$
A T E=E\left(Y^{1} \mid T=1\right)-E\left(Y^{0} \mid T=0\right)
$$

where $Y^{l}$ is rice output of participants in agricultural training and $Y^{0}$ is rice output of non-participants in agricultural training, $\mathrm{T}=1$ refers to the treated category (farmers who received training) and $\mathrm{T}=0$ denotes the untreated category (farmers without training). In the situation of a randomised design, $E\left(Y^{1} \mid T=1\right)-E\left(Y^{0} \mid T=0\right)$ equals zero and the estimate of ATE provides an unbiased estimate of impact (DILLON, 2008). This condition does not hold when there is sample selection bias. In order to deal with the possible problem of selection bias, the average treatment effect on the treated (ATT) is estimated, given a vector of household characteristics $\mathrm{X}$ as shown in equation (6) ${ }^{1}$.

$$
\begin{gathered}
A T T=E(\Delta \mid \mathrm{X}, T=1)=E\left(Y^{1}-Y^{0} \mid \mathrm{X}, T=1\right)= \\
\mathrm{E}\left(Y^{1} \mid \mathrm{X}, T=1\right)-E\left(Y^{0} \mid \mathrm{X}, T=0\right)
\end{gathered}
$$

Empirical models

The empirical probit model for estimating participation in training is specified as follows:

$$
A_{i}^{*}=\gamma_{0}+\sum_{j=1}^{7} \gamma_{j} Z_{j i}+u_{i}
$$

where $Z_{i}$ refers to the independent variables affecting participation in training: $Z_{1}=\operatorname{sex}, Z_{2}=$ age, $Z_{3}=$ extension contact, $Z_{4}=$ membership in farmer organisation, $Z_{5}=$ access to microcredit, $Z_{6}=$ degree of specialization in rice production, and $Z_{7}=$ household income. $\gamma$ is a vector of parameters to be estimated, and $u_{i}$ is the random error term.

Similarly, the Cobb-Douglas production function (the substantive equation) was specified as

$$
\ln Y_{i}=\beta_{0}+\sum_{k=1}^{2} \beta_{k} D_{k i}+\sum_{j=1}^{6} \beta_{j} \ln X_{j i}+\delta A_{i}+u_{3 i}
$$

where $\ln$ is natural logarithm, $Y_{i}$ denotes rice output of the $i^{\text {th }}$ farmer and $\mathrm{j}$ is the jth input used in production. $D_{k i}$ is the kth intercept dummy variable: $D_{1}$ is an irrigation dummy and $D_{2}$ is a location dummy. $X_{1}$ to $X_{6}$ are production inputs, namely land, labour, seed, fertilizer, expenditure, and capital. $A_{i}$ is an index variable for whether or not the farmer participated in training and $\delta$ measures the effect of training on output. $u_{3 i}$ are as previously defined. 
The variables in the study are defined in Table 1.

Table 1: Definition of variables used in the study

\begin{tabular}{|c|c|c|}
\hline Variable description & Definition & Expected sign \\
\hline Gender Dummy: & 1 for male; 0 for otherwise & + \\
\hline Age & $\begin{array}{l}\text { Age of the household head in } \\
\text { years }\end{array}$ & $+/-$ \\
\hline Extension contact & $\begin{array}{l}\text { Number of extension contacts } \\
\text { in the season }\end{array}$ & + \\
\hline Group membership & $\begin{array}{l}\text { Dummy: } 1 \text { if member; } 0 \\
\text { otherwise }\end{array}$ & + \\
\hline Access to microcredit & $\begin{array}{l}\text { Dummy: } 1 \text { if credit user; } 0 \\
\text { otherwise }\end{array}$ & + \\
\hline Production system & $\begin{array}{l}\text { Dummy: } 1 \text { if user of irrigation; } \\
0 \text { otherwise }\end{array}$ & + \\
\hline Degree of specialization & $\begin{array}{l}\text { Proportion of land area al- } \\
\text { located to rice }\end{array}$ & + \\
\hline Household income & $\begin{array}{l}\text { Household income in Ghana } \\
\text { cedi }\end{array}$ & + \\
\hline Region Dummy: & $\begin{array}{l}1 \text { for Northern Region; } 0 \\
\text { otherwise }\end{array}$ & $+/-$ \\
\hline $\begin{array}{l}\text { Participation in training } \\
\text { Dummy: }\end{array}$ & 1 for participants; 0 otherwise & + \\
\hline \multicolumn{3}{|l|}{ Production variables } \\
\hline Output & $\begin{array}{l}\text { Natural log of rice output in } \\
\text { kilograms }\end{array}$ & + \\
\hline Farm size & $\begin{array}{l}\text { Natural log of land size in } \\
\text { hectares }\end{array}$ & + \\
\hline Labour & $\begin{array}{l}\text { Natural log of labour input in } \\
\text { man-days }\end{array}$ & + \\
\hline Seed & $\begin{array}{l}\text { Natural log of seed in kilo- } \\
\text { grams }\end{array}$ & + \\
\hline Fertilizer & $\begin{array}{l}\text { Natural log of fertilizer in } \\
\text { kilograms }\end{array}$ & + \\
\hline Other costs & $\begin{array}{l}\text { Natural log of other variable } \\
\text { costs in Cedis }\end{array}$ & + \\
\hline Farm capital & $\begin{array}{l}\text { Natural log of farm capital in } \\
\text { Cedis }\end{array}$ & + \\
\hline
\end{tabular}

As indicated in the table, most of the variables are expected to have a positive effect on training and smallholder rice production. Age and location of the farm are the variables expected to have indeterminate effect on training and rice production. Geographical location is expected to affect access to training and rice production but the direction of effect is indeterminate. Similarly, younger farmers may be more progressive farmers and more likely to participate in agricultural training compared to older farmers. However, older farmers with more years in farming are likely to be favoured in the selection of farmers for training as a result of their social standing.

\section{RESULTS AND DISCUSSION}

\section{Characteristics of the respondents}

Participants in agricultural training were older, had larger farm size and higher output. In addition, participants in training used more inputs in production and allocated more land to rice cultivation. Access to extension, microcredit and irrigation was also higher for participants in training, who also had higher membership in farmer groups. The characteristics of the respondents indicate that several socio-economic and demographic factors are likely to influence participation of smallholder farmers in agricultural training.

Table 2: Characteristics of the respondents according to participation status

\begin{tabular}{|l|c|c|c|c|c|}
\hline Variables & $\begin{array}{c}\text { Training } \\
(\mathrm{n}=170)\end{array}$ & $\begin{array}{c}\text { No training } \\
(\mathrm{n}=130)\end{array}$ & t-test $^{1}$ & & \\
\hline Mean & Std. Dev. & Mean & $\begin{array}{c}\text { Std. } \\
\text { Dev. }\end{array}$ & \\
\hline Sex & 0.77 & 0.42 & 0.80 & 0.40 & -0.61 \\
\hline Age & 42.3 & 11.8 & 39.8 & 12.9 & $1.73^{*}$ \\
\hline $\begin{array}{l}\text { Extension } \\
\text { contact }\end{array}$ & 4.44 & 5.83 & 1.83 & 3.81 & $4.42^{* * *}$ \\
\hline $\begin{array}{l}\text { Asso- } \\
\text { ciation } \\
\text { member- } \\
\text { ship }\end{array}$ & 0.80 & 0.40 & 0.48 & 0.50 & $6.20^{* * *}$ \\
\hline $\begin{array}{l}\text { Access to } \\
\text { micro- } \\
\text { credit }\end{array}$ & 0.46 & 0.50 & 0.32 & 0.47 & $2.50^{* * *}$ \\
\hline $\begin{array}{l}\text { Produc- } \\
\text { tion } \\
\text { system }\end{array}$ & 0.58 & 0.50 & 0.40 & 0.49 & $3.07^{* * *}$ \\
\hline $\begin{array}{l}\text { Degree of } \\
\text { special- } \\
\text { ization }\end{array}$ & 49.4 & 26.9 & 40.1 & 21.6 & $3.21^{* * *}$ \\
\hline $\begin{array}{l}\text { House- } \\
\text { hold } \\
\text { income }\end{array}$ & 1.05 & 0.88 & 0.94 & 0.83 & 1.04 \\
\hline Region & 0.32 & 0.47 & 0.35 & 0.48 & -0.41 \\
\hline Output & 1894 & 2199 & 1328 & 1930 & $2.33^{* *}$ \\
\hline Farm size & 0.93 & 0.72 & 0.76 & 0.62 & $2.06^{* * *}$ \\
\hline Labour & 68.9 & 51.3 & 58.1 & 34.6 & $2.06^{* *}$ \\
\hline Seed & 171.4 & 170.9 & 140.5 & 130.6 & $1.71^{*}$ \\
\hline Fertilizer & 315.9 & 344.9 & 261.5 & 336.2 & 1.36 \\
\hline $\begin{array}{l}\text { Other } \\
\text { costs }\end{array}$ & 200.7 & 177.2 & 167.0 & 204.8 & 1.52 \\
\hline Capital & 145.6 & 159.6 & 105.7 & 137.2 & $2.28^{* * *}$ \\
\hline
\end{tabular}

${ }^{1}$ The t-test indicates a test of mean difference between the two groups. $* * *, * *$ and $*$ stand for statistical significance at 1 , 5 and 10 percent level, respectively.

\section{Analysis of factors influencing participation in agricultural training}

Participation in agricultural training was analysed using a binary probit model. The maximum likelihood estimates of the binary probit model are presented in table 3 . The probit model indicated that participation in agricultural training increases with access to extension and microcredit as well as membership in farmer groups. 
Table 3: Probit analysis of the factors influencing participation in agricultural training

\begin{tabular}{|l|l|l|l|}
\hline Variables & Coefficient & Std. Error & $\mathrm{P}>|\mathrm{z}|$ \\
\hline Sex & 0.029 & 0.195 & 0.880 \\
\hline Age & 0.009 & 0.006 & 0.160 \\
\hline Extension contact & $0.058^{* * *}$ & 0.018 & 0.001 \\
\hline Association membership & $0.749^{* * *}$ & 0.168 & 0.000 \\
\hline Access to microcredit & $0.393^{* *}$ & 0.166 & 0.018 \\
\hline Degree of specialization & $0.008^{* *}$ & 0.003 & 0.015 \\
\hline Household income & 0.027 & 0.093 & 0.772 \\
\hline Constant & $-1.455^{* * *}$ & 0.392 & 0.000 \\
\hline Lambda (口) & $-0.282 * *$ & 0.128 & 0.028 \\
\hline Rho & -0.410 & & \\
\hline Sigma & 0.686 & & \\
\hline
\end{tabular}

***, ** and * indicate statistical significance at the 1,5 and 10 percent level, respectively.

Contact with extension agents increased the likelihood of participation in training because extension agents link farmers to training institutions and organisations working with farmers. Access to extension by smallholders promotes knowledge acquisition on innovations and existing opportunities including training programmes. This view is supported by AWUNYOVITOR et al. (2013). Extension agents play an important role in linking rural farmers to institutions providing training to farmers. Hence contact with agricultural extension staff is anticipated to increase the likelihood of participation in agricultural training.

The likelihood of participation in training also increased with membership in farmer organisation at $1 \%$ significance level. The result is to be expected because farmer-groups are important conduits for extension delivery and mobilization of farmers for training programmes. Any available avenue through which farmers receive information on existing opportunities for training is likely to enhance participation in agricultural training. As indicated by BINAM et al. (2005), belonging to a farmer group enhances access to information while NAKANWAGI and HYUHA (2015) associated participation in farmer groups with knowledge sharing.

Access to microcredit was positively associated with participation in agricultural training and significant at 5\% level. Hence, smallholders who used credit in farming were more likely to participate in training programmes. Respondents who accessed credit for production may be more progressive farmers who are likely to be abreast with current opportunities for training. Furthermore, the result showed that farmers with greater specialization in rice production were more likely to participate in training. The result, which was significant at 5\% level, shows that highly specialized farmers exhibit a higher propensity to participate in training activities. Farmers with greater specialization in rice production are more likely to be identified and selected for training programmes targeted at rice farmers.

\section{The effect of training on rice output}

The treatment effect model was used to measure the effect of training on rice output of smallholder farmers in northern Ghana. The training participation equation was estimated and the predicted values of participation were used to construct the selection control factor (a) which is equivalent to the inverse Mill's ratio (IMR). This enabled measurement of the pure effects of training on the response variable (rice output). The result is presented in Table 4.

Table 4: Maximum likelihood estimates for the parameters of the treatment effect model

\begin{tabular}{|l|l|l|l|}
\hline Variable & Coefficient & Std. Error & $\mathrm{P}$ - value \\
\hline Production system & $0.904 * * *$ & 0.099 & 0.000 \\
\hline Regional dummy & $0.514 * * *$ & 0.097 & 0.000 \\
\hline Farm size & $0.233^{* *}$ & 0.117 & 0.046 \\
\hline Labour & $0.230^{*}$ & 0.120 & 0.055 \\
\hline Seed & $0.173^{* * *}$ & 0.064 & 0.006 \\
\hline Fertilizer & $0.099^{* * *}$ & 0.030 & 0.001 \\
\hline Other costs & $0.103^{* * *}$ & 0.035 & 0.004 \\
\hline Capital & 0.011 & 0.037 & 0.756 \\
\hline Training dummy & $0.453^{* *}$ & 0.198 & 0.022 \\
\hline Constant & $-1.205^{* * *}$ & 0.141 & 0.000 \\
\hline
\end{tabular}

$* * *, * *$ and $*$ stand for statistical significance at 1,5 and 10 percent level, respectively. Dependent variable is rice output. Wald Chi2 (9) $=627.03$, Prob $>$ Chi (2) $=0.000$.

The coefficients of all the traditional input variables have positive signs indicating that the monotonicity assumption of the production function is satisfied. Hence an increase in input leads to a corresponding increase in output. The partial output elasticity of land shows that increasing farm size by $1 \%$ increases output by $0.23 \%$. Similarly, $1 \%$ increase in labour, seed and fertilizer increases output by $0.23 \%, 0.17 \%$ and $0.09 \%$ respectively. The partial output elasticities of expenditure (other costs) and capital indicate that $1 \%$ increase in other costs and capital increases output by $0.10 \%$ and $0.01 \%$ respectively. Farm size and labour therefore have the highest partial output elasticities, followed by seed. The sum of the output elasticities with respect to the six conventional input variables provides a measure of returns to scale (RTS). The RTS is 0.849 , implying decreasing (diminishing) returns to scale in rice production in the study area. The result is consistent with BAAWUAH (2015) in his study involving lowland rice farmers in Ghana as well as KUWORNU et al. (2013) who found maize farmers in Ghana to operate at decreasing returns to scale.

The coefficients of access to irrigation and the regional dummy variables indicate that irrigation and geographical location affect rice productivity of smallholders in northern Ghana. Irrigation enhances rice productivity as indicated by the positive coefficient of the irrigation dummy variable. The result is consistent with ADEOTI et al. (2009) who identified treadle pump irrigation technology as an important technological innovation to increase efficiency and output of 
smallholder farmers in Ghana. Similarly, farmers located in the Northern Region have higher productivity than their counterparts in the upper East Region.

The variable of interest, training is positive and significant at 5\% level, meaning that farmers who received training in rice production obtained higher rice output than those who did not receive training. This is an important finding that justifies investment in training programmes that meet the specific needs of small-scale farmers in addition to the general extension advice given to farmers. As indicated by STEWART et al. (2015), two categories of interventions used to enhance food security and reduce poverty are training of farmers on new production practices and inputs, and encouraging the adoption of agricultural innovations and new technologies.

The significance of lambda () in Table 3 implies that selectivity bias was present in the model and that if it was no corrected, the estimated coefficients, including the training participation variable would have been biased, meaning that the pure effects of the explanatory variables on output could not be measured. The application of the average treatment effect model effectively corrected for the selectivity bias and ensured that the estimated coefficients were freed from the effects of unobserved factors that correlated with rice output.

Results of the average treatment effect of training on yield, total output and labour productivity

Table 5 presents the results of estimates of the average treatment effect of training (ATT) on rice output, yield (land productivity) and labour productivity. Nearest neighbour matching was used to match participants in training to corresponding non-participants based on their propensity scores (estimated probability of participation in agricultural training). The procedure was implemented using Stata's treatment effects command teffects.

Table 5: Estimates of the average treatment effect of training on rice output, yield and labour productivity

\begin{tabular}{|l|c|c|c|}
\hline Outcome variable & ATT $\square$ & Robust Std. Err. & $\mathrm{P}>|\mathrm{z}|$ \\
\hline Total output & $796.9^{* * *}$ & 168.0 & 0.000 \\
\hline Labour productivity & $7.340^{* *}$ & 2.926 & 0.012 \\
\hline $\begin{array}{l}\text { Yield (land produc- } \\
\text { tivity) }\end{array}$ & 395.3 & 247.3 & 0.110 \\
\hline
\end{tabular}

$\square$ indicates the average treatment effect of training on the outcome variables. $* * *$ and $* *$ indicate for statistical significance at 1 and 5 percent level, respectively.

From the estimation results, training had a significant effect on rice output and labour productivity. On average, participation in agricultural training increased rice output of participants by $797 \mathrm{~kg}$. This increase in output is statistically significant at 1 percent level. In addition, participation in training led to an increase in labour productivity of $7.3 \mathrm{~kg} / \mathrm{man}$ day, which is statistically significant at 5 percent level. The result is consistent with the extant literature which indicates that training enhances human capital resulting in higher business profitability and productivity of labour (EVANS and LINDSAY, 1999). Hence, the result is consistent with a priori expectation. Furthermore, participation in training led to an increase in yield (land productivity) of $395.3 \mathrm{~kg} / \mathrm{ha}$ but the result is not statistically significant. The authors therefore conclude from the findings of the study that training enhances human capital of smallholder farmers and leads to improved farm performance in line with a priori expectations. However, the productivity-enhancing effect of training does not have the same effect on the different productivity measures as a result of other limiting factors in production. Whereas training has a direct impact on human capital, resulting in higher labour productivity, the effect on yield (land productivity) is indirect and thus relatively modest. This is because productivity of land (i.e. yield) depends on several other factors such as inherent fertility of the land, land management practices, incidence of pests and diseases, among others (FOLNOVIC, 2015; GUTIERREZ, 2003; SHITTU et al. 2010). Hence, efforts to improve agricultural productivity among smallholders should go beyond the provision of training and extension advice to include provision of agricultural credit and irrigation that improve farm yield.

\section{CONCLUSION}

The study examined the factors influencing participation in agricultural training and the effects of participation on output and labour productivity of smallholder rice farmers in northern Ghana. The study accounted for selection bias using a treatment effect model and measured the direct effect of training on farm performance. Participation in training was found to have a positive and significant effect on rice output and labour productivity. On average, output and labour productivity gains of $797 \mathrm{~kg}$ and $7.3 \mathrm{~kg} / \mathrm{man}$-day respectively were obtained from participation in agricultural training. There was a positive effect of training on yield but the result was not significant. The study concludes that agricultural training has direct effect on labour productivity and farm output. This calls for the need to intensify training of smallholder farmers in modern rice production practices. Furthermore, agricultural training alone is inadequate to improve the yield of farmers. This is because other factors such as soil fertility management and control of pests and diseases are important in determining farmers yield. Finally, the study showed that institutional factors play an important role in smallholders' participation in agricultural training which promotes higher output and labour productivity of farmers. Hence, improving access to agricultural extension and microcredit as well as encouraging farmers to join farmer-based organisations are necessary to increase rice production in Ghana.

\section{REFERENCES}

Adeoti, A., Boubacar, B., Regassa, N., Kamara, A. (2009): The impact of treadle pump irrigation technology adoption on poverty in Ghana. The Journal of Agricultural Education and Extension, 15(4): 357-369.

Awunyo-Vitor, D., Bakang, J., Cofie, S. (2013): Estimation of farm level technical efficiency of small-scale cowpea production in Ghana. American-Eurasian Journal of Agricultural and 
Environmental Sciences, 13: 1080-1087.

Baawuah, G. (2015): Production risk and technical efficiency of lowland rice farms in Ashanti Region, Ghana. MPhil thesis in Agricultural Economics, School of Agriculture, University of Ghana, Legon.

Binam, JN., Tonye, J., Wandji, N. (2005): Sources of technical efficiency among small holder maize and peanut farmers in slash and burn agricultural zone of Cameroon. Journal of Economic Cooperation, 26: 193-210.

Brenya, P. (2014): The effect of human capital development on employee commitment in the Judicial Service: A case study of Western Region. MBA Thesis, School of Business, Kwame Nkrumah University of Science and Technology.

Clarke, N., Bizimana, JC., Dile, Y., Worqlul, A., Osorio, J., Herbst, B., Richardson, JW., Srinivasan, R., Gerik, TJ., Williams, J., Jones, C. A. (2017): Evaluation of new farming technologies in Ethiopia using the Integrated Decision Support System (IDSS). Agricultural Water Management, 180: 267-279.

Colombo, E., Stanca, L. (2014): The impact of training on productivity: evidence from a panel of Italian firms", International Journal of Manpower, 35(8): 1140-1158. https://doi. org/10.1108/IJM-08-2012-0121. Accessed 1 July 2018.

Diao, X., Hazell, P., Thurlow, J. (2010): The role of agriculture in African development. World Development, 38(10): 13751383.

Evans, JR., Lindsay, WM. (1999): The management and control of quality (4th ed). Cincinnati, Ohio: South-Western College Publishing.

FAO (2012): IFAD: Economic growth is necessary but not sufficient to accelerate reduction of hunger and malnutrition: The State of Food Insecurity in the World 2012. FAO, Rome 2012: 1-65. FAO, Rome.

Gautam, S., Schreinemachers, P., Md. Uddin, N., Srinivasan, R. (2017): Impact of training vegetable farmers in Bangladesh in integrated pest management (IPM). Crop Protection, 102 (2017): 161-169.

Girgin, A. (2011): The role of education in agricultural productivity: the case of Village Institutes in Turkey, 19401966. Master thesis. Lund University, Sweden.

Gutierrez, L. (2003): Why is agricultural labour productivity higher in some countries than others? Agricultural Economic Review, 3(1): 58 - 78.

Ismail, R., Noor, ZM., Awang, AH. (2011): Impact of training on firms' output and labour productivity. Journal of Business and Policy Research, 6(1): 130-144.

Kuwornu, JKM., Amoah, E., Seini, W. (2013): Technical Efficiency analysis of maize farmers in the Eastern Region of Ghana. Journal of Social and Development Sciences, 4(2): 8499.

Lucas, RE (1993): Making a miracle. Econometrica, 61: 251272.

Maddala, GS (1983): Limited dependent and qualitative variables in econometrics. Econometric Society Monographs No. 3. Cambridge University Press.

Nakano, N., Tsusaka, T. W., Aida, T., Pede, VO (2015): The impact of training on technology adoption and productivity of rice farming in Tanzania: Is farmer-to-farmer extension effective? JICA-RI Working Paper No. 90. March 2015.

Nakanwagi, TT., Hyuha, TS (2015): Technical efficiency of milk producers in cattle corridor of Uganda: Kiboga District Case. Modern Economy, 6: 846-856. http://dx.doi.org/10.4236/ me.2015.67079. Accessed 2 July 2018.

Pardey, PG., Roseboom, J., Craig, BJ. (1992): A yardstick for international comparisons: an application to national agricultural research expenditures. Economic Development and Cultural Change, 40: 333-349.

Rosegrant, MW., Evenson, RE. (1992): Agricultural productivity and sources of growth in South Asia. American Journal of Agricultural Economics, 74 August: 757-761.

Shittu, AM., Ashaolu, OF., Philip, BB. (2010): Determinants of agricultural labour productivity in the West African subregion, 1970-2004. Journal of Humanities, Social Sciences and Creative Arts, 5(1):101-110.

SRID-MoFA (2011): Crop production estimates 2010. Published by the Statistics, Research and Information Directorate (SRID) of the Ministry of Food and Agriculture (MoFA), Ghana.

Stewart, R., Langer, L., Rebelo Da Silva NR., Muchiri, E., Zaranyika, H., Erasmus, Y., Randall, N., Rafferty, S., Korth, M., Madinga, N., de Wet, T. (2015): The effects of training, innovation and new technology on African smallholder farmers' economic outcomes and food security: a systematic review, 3ie Grantee Final Review. London: International Initiative for Impact Evaluation (3ie).

Folnovic, T. (2015): Factors that affect agricultural productivity. Available at http://blog.agrivi.com/post/factors-that-affectagricultural-productivity. Accessed 17 July 2018.

Wiggins, S. (2000): Interpreting changes from the 1970s to the 1990 s in African agriculture through village studies. World Development, 28(4): 631-662.

Wordofa, MG., Sassi, M. (2017): Impact of farmers' training centres on household income: evidence from propensity score matching in Eastern Ethiopia. Social Science, 7(4):1-12. doi:10.3390/socsci7010004. Accessed 12 July 2018. 
